will commemorate in April next the one hundred and fiftieth anniversary of the death of Petrus Camper, physician, anatomist, obstetrician and artist. The name of Camper is perhaps now most frequently recalled in connexion with his contributions to the foundation of craniology as a scientific study. He was the first to make use of the facial angle-an invention apparently of the artist Dürer-as a factor in racial discrimination. The occasion is not without special interest to science in Great Britain, as it was during Camper's visit to London in 1748, through his association with Pringle, Mead and Pitcairn, and his familiarity with the collections of Sir Hans Sloane, Collinson and others that his interest in natural history was stimulated, if not actually aroused. Camper was born on May 11, 1722, at Leyden, where he was educated and took his degree in philosophy and medicine in 1746. He afterwards held professorial chairs at Franeker (1750), Amsterdam (1755) and Groningen (1763), being appointed councillor of State in 1787 , two years before his death in 1789. He was among the most distinguished men of science of international standing of his day. Not only was he a fellow of the Royal Society of London, but also he shared with Boerhaave the then unique honour for a foreigner of membership of the Paris Academy of Sciences. His works, of which a collected edition was published in Paris in 1803, covered a wide field, ranging from the physical education of children to detailed studies in anatomy, physiology and natural history. Among his anthropological treatises were studies of the origin and colour of negroes, and on the variation of the facial angle in different races.

\section{Preservation of Wildfowl}

AN amendment put forward by the promoters of the Wild Birds (Duck and Geese) Protection Bill has secured the withdrawal of the opposition, on behalf of shore-shooters, which has been holding up the Bill in the House of Commons, and it is to be hoped that it will now have a successful and rapid passage. The amendment provides separate close-times for wild duck and geese above and below high-tide mark ; further, the date of the period of prohibition of import of wildfowl will commenee on February 1 . This last is an extremely important feature of the Bill, for it stops the demand for duck caught in decoys on the Continent during the breeding season. The Bill, which is promoted by the International Committee for Bird Preservation (British Section) and has the full support of the Government, is part of a big international scheme to preserve the stock of wildfowl in Europe. The accumulation of adverse effects of modern civilization is having a most serious effect on wild duck and geese. Cold storage, facilities of transport, draining of land, development of arctic areas and over-commercialization by means of decoys are but a few of the factors which are depriving wildfowl of their nesting and resting grounds and causing their destruction on a vast scale. The shooting season is also admittedly too long in many countries. Sweden has already taken drastic steps by prohibiting all shooting in several of its largest provinces, Denmark and Germany have greatly restricted their shooting seasons, and other European countries are alive to the necessity of action to safeguard the general stock of wildfowl before it is too late. The state of affairs in America, where wildfowl have been reduced to a perilously low number, is only too gloomy an example.

\section{Engineering and Social Science}

IN a recent address to the Manchester and District Association of the Institution of Civil Engineers on the work of the civil engineer in relation to social and international problems, Mr. R. D. Brown urged that engineers are no better qualified for statesmanship or politics than the medical man, the lawyer, the psychologist, the physicist or the parson. Engineering science has nothing to do with solving the social, economic and political problems of mankind, and the scientific and the political minds and methods of working have nothing in common. While engineers should be mindful of their duties as citizens, they can only engage in politics if they are prepared to give up engineering altogether and devote their time and energy to a new way of life. Mr. Brown is sceptical of the value of the proposed Council of Engineers, and recommends rather that any man of science, whether an engineer or not, who desires to help in this matter to get into touch with the committee of the newly formed Division for the Study of the Social and International Relations of Science of the British Association. The committee will require all the help it can obtain, whether from engineers, chemists, biologists, publicity experts or others. Mr. Brown referred to the importance in thinking about such problems of divesting the mind of all prejudice, superstition and humbug, and of laying aside all preconceived political, social or racial notions. He considered the committee's work might prove to be the most important investigation ever undertaken by the British Association.

\section{Steel Manufacture in South Wales}

THE project of a new steel works and rolling mill at Ebbw Vale in Monmouthshire designed on the latest lines and including a hot strip rolling mill for continuous production has aroused considerable interest. The size of the undertaking may be estimated from the fact that the plant cost about ten million pounds, and is designed to give an output of 600,000 tons per annum of tin plate and sheet steel of the highest quality. The raw materials, coal and limestone, are in the immediate vicinity and transport facilities are good. The electrical part of the equipment is very complete. The works have an installed capacity of $250,000 \mathrm{kw}$. and will consume approximately 200 million units per annum. The Victoria generating station of the former Ebbw Vale Company has been largely reconstructed, but to provide the greatly increased demand of the new plant a grid supply at $132 \mathrm{kv}$. is brought from the Upper Boat power station, a distance of eighteen miles. The supply of iron ore for the works is obtained from Northamptonshire, and ample coal is obtainable 
from the neighbouring collieries. The coke oven plant is designed to deal with 1,370 tons of coal a day. a complete by-product recovery plant being provided, The two blast furnaces have been entirely reconstructed, the output of each being increased to 3,500 tons of pig iron. The molten iron from the blast furnaces is taken direct to the steel works, but any surplus not required at the moment is diverted to a pig-casting shop. The molten metal is first poured into a 1,400-ton mixer, where it is kept in a molten state until it is required to charge the furnaces. The molten steel is discharged from the furnaces at floor level and is cast into ten-ton ingots.

\section{River Control in Great Britain}

A BROADShEET issued by Political and Economic Planning (PEP) deals with the difficulties which regionalism presents to the efficient operation of specialized and technical services, as exemplified in the control of rivers. Already the Ministry of Health, the Ministry of Agrieulture and Fisheries, the Ministry of Transport, the Electricity Commissioners, the Board of Trade, the Mines Department, the Home Office and the Development Commissioners are concerned with different aspects of water supply and the control of rivers in Great Britain. The Land Drainage Act of 1930 was a consolidating and amending measure based on the recommendations of a Royal Commission and created some forty-nine catchment areas which cover the greater part of England and Wales, but the process of constituting and reorganizing drainage boards within catchment areas is not yet complete. Navigable rivers are controlled mainly by 51 public bodies, and waterways are owned by the railways and 31 other companies.

IN the even more important matter of water supply, there are ot present $\mathbf{7 8 2}$ local authorities and 50 joint authorities supplying, besides $236 \mathrm{com}$ panies and 1,053 private proprietors. To secure further rationalization and conservation of water supplies, nine regional advisory committees have been created, and a sub-committee of the Advisory Water Committee recently recommended that other committees should be created in the Greater Metropolitan Area, South Wales and the North-East. The possibility of damage to mains and reservoirs during air raids makes working agreements even more essential. The control of sewage presents yet another problem calling for co-ordination, while there are nearly fifty fishery boards concerned to prevent pollution of rivers, which may come into conflict with the navigation authorities. Moreover, town and country planning schemes are required to prevent ribbon development along river banks and undue pressure to develop sites. It is suggested that the Thames Conservancy Board, which is both a conservancy and catchment authority and has power over pollution and fisheries, is a model of what is required. How far it would be possible to entrust the general supervision of all water interests to one central department is a matter for discussion.

\section{British Museum (Natural History) : Recent Acquisitions}

The Trustees have purchased for the Department of Mineralogy uncut erystals of topaz, sapphire, and a set of seven rough crystals of ruby from Mogok, while cut stones are represented by a good example of deep lilac-coloured kunzite and a remarkable clear yellow cassiterite, cut from a stone from Uganda. A small diamond of considerable interest in the history of diamond-mining has been presented by Sir Ernest Oppenheimer. It is the first diamond taken from the first of the Kimberley diamond mines-the Jagersfontein-and was found by William Wreford Paddon. Dr. Stanley Smith, University of Bristol, has presented a specimen of natural coke showing columnar structure, from a quarry near Cockfield, County Durham. The coke was formed where a coal seam had been burnt out by a basalt dyke. Miss Beatrice O. Corfe has presented to the Department of Botany more than three hundred paintings of British flowers. The Department already possesses a number of Miss Corfe's paintings which were purchased some years ago. The paintings are artistic and at the same time botanically sound, and a number of them suitably adapted have been reproduced in the Museum series of botanical picture postcards. As a result of a short expedition to St. Lucia undertaken for the Museum by Mr. Harold E. Box, more than three hundred flowering plants and ferns were obtained chiefly from the higher altitudes of the mountains in the interior of the island. Unfortunately, Mr. Box's visit coincided with the almost unprecedented rainfall of November last, and twenty out of twenty-eight days had to be spent in camp or indoors.

\section{Fisheries Research in Hong Kong}

AT the recent meeting of the British Association in Cambridge, the president of Section D (Zoology), in a highly important address, directed attention to the fact that the British Empire as a whole is regrettably deficient in fisheries research and administration. This is especially true of British territories in the Far East. In consequence, highly skilled and intensely industrious Japanese fishermen have in recent years been exploiting practically all the great fishing grounds of the Pacific region and landing large quantities of fish at most of the principal fishmarkets-both British and foreign-along the coasts of China, India, Philippines, Malaya and Dutch East Indies. It is highly gratifying, therefore, to note that the University of Hong Kong recently has published a small handbook ("Common Marine Food Fishes at Hong Kong”. By G. A. C. Herklots and S. Y. Lin. Pp. 75. Hong Kong: G. A. C. Herklots, The University. n.d. n.p.) written in both English and Chinese, describing forty of the commonest food fishes landed at Hong Kong fish-markets. Each fish has been given its scientific name, Chinese name or names, and an English name--in some instances specially coined for this book. This is followed by a brief but useful description accompanied by a blackand-white illustration, with notes on distribution, seasonal abundance, price and food value. At the end of the book are set out twelve Chinese and seventeen European recipes for the cooking of fish dishes. 